\title{
KONFLIK SOSIAL DALAM NOVEL MARANSI
}

\author{
Arif Rahman Hakim ${ }^{1}$, Herry N Hidayat ${ }^{2}$ Pramono $^{3}$ \\ arifrahman@gmail.com* \\ Fakultas Ilmu Budaya Universitas Andalas ${ }^{1,2,3}$
}

\begin{abstract}
ABSTRAK
Penelitian ini mendeskripsikan konflik-konflik tokoh yang mengalami pertikaian kondisi sosial di dalam novel Maransi. Konflik yang dibahas dalam novel ini berupa perkara-perkara rumah gadang, tanah pusaka, gelar pusaka, hargadiri dan peran mamak dalam membimbing kemenakan. Penelitian ini dibatasi pada konflik sosial yang terjadi antara mamak dan kemenakan.

Teknik pengumpulan data yang dipakai dalam penelitian berupa studi kepustakaan. Data terdiri dari data primer berupa teks yang bersumber pada novel Maransi dan data sekunder berupa referensi yangberdekatan dengan objek penelitian. Teknik analisis data dengan memilah dan memilih konflik-konflik yang menunjukkan permasalahan pada mamak dan kemenakan.

Sesuai dengan tujuan penelitian, hasil analisis yang dihasilkan menunjukkan konflik-konflik sosial berupa pergeseran peran mamak sebagai orang yang dituakan dalam kaum pada pengambilan keputusan mendirikan rumah gadang. Hilangnya citra kepemimpinan mamak dan datuk di masyarakat Minangkabau yang lebih mengedepankan kepentingan pribadinya dan mendahulukan kepentingan keluarga dan anaknya. Terjadinya pergeseran peran mamak dalam mengendalikan harta pusaka dan sako sebagai warisan yang harus diturunkan kepada kemenakan. Kurangnya peran mamak berupa bimbingan kepada kemenakan. Tidak adanya komunikasi yang kondusif antara mamak dan kemenakan.
\end{abstract}

Kata-kata kunci: konflik sosial, tokoh, peran, mamak, kemenakan, Minangkabau

\section{ABSTRACT}

This research describes the characters' conflicts who experience disputes over social conditions in the novel $M$ Transparency. The conflicts discussed in this novel are in the form of cases of rumah gadang, inheritance land, heirloom titles, dignity, and the role of the mamak in guiding the nephews. This research is limited to the social conflicts that occur between mamak and nephews.

The data collection technique used in the research was a literature study. The data consist of primary data in the form of text from the novel Maransi and secondary data in the form of references close to the object of research. The data analysis technique is by sorting and selecting conflicts that show problems for mamak and nephews.

Following the research objectives, the analysis results show social conflicts in the form of role shift of the mamak as the community's elder in deciding to build a rumah gadang. The loss of the image of mamak and datuk leadership in the Minangkabau community prioritizes their interests and prioritizes the interests of their families and children. There has been a role shift of the mamak in controlling inheritance and sako as inheritance must be passed on to kamanakan. The lack of a mamak role in the form of guidance to nephews. The absence of conducive communication between mamak and kamanakan.

Keywords: social conflicts, characters, roles, mamak, kemanakan, Minangkabau

Jurnal Elektronik WACANA ETNIK - Vol 9 No 1, 2020, (1 - 18) p ISSN 2089-8746, e ISSN 2302-7142

Submit: Januari 2020. Diterima: Maret 2020. Publikasi: April 2020. 


\section{PENGANTAR}

Karya sastra mengangkat berbagai bentuk fenomena sosial masyarakat dari hasil renungan pengarang melalui konflik, latar, tokoh dan tema yang ada di dalamnya. Satu di antara karya sastra yang terbentuk dari konflik yakni novel Maransi. Novel Maransi menggambarkan pergeseran peran mamak dan konflik- konflik yang bertentangan dengan kondisi sosial masyarakat Minangkabau.

Maransi merupakan novel nominasi sayembara Dewan Kesenian Jakarta tahun 2016 yang menceritakan pergeseran norma sosial, kekuasaan, adat hingga kondisi ekonomi masyarakat Minangkabau. Kondisi sosial masyarakat yang mengalami perubahan terhadap tugas dan kewajiban niniak mamak, hak dan peranperempuan dalam kaum, pewarisan harta pusaka, serta perkara gelar sako pada sebuah kaum.

Novel Maransi dipilih sebagai objek penelitian berdasarkan pertimbangan-pertimbangan sebagai berikut: Pertama, novel Maransi merupakan novel yang menggambarkan kondisi sosial masyarakat dengan lokalitas Minangkabau. Novel ini menceritakan perubahan-perubahan sosial dari peran, kedudukan serta hak-hakyang harus dilakukan seorang mamak terhadap kemenkannya. Selain itu, peran dan tanggung jawab perempuan di Minangkabau juga mengalami perubahan dari akibat pergeseran kedudukannya di rumah gadang. Kedua, gaya penulisan yang digunakan dalam novel Maransi memiliki dialek penuturan orang Minangkabau. Adanya dialek yang biasa diucapkan orang Minang dengan gaya tutur dari dialog tokoh di dalam novel. Ketiga, tokoh dalam novel Maransi memiliki karakter yang menggambarkan kondisi sosial yang terjadi di Minangkabau. Satu di antaranya, tokoh Sunur sebagai mamak diceritakan sebagai perwujudan mamak yang hadir dimasyarakat Minangkabau dengan konflik sosial di dalamnya. Sehingga ada nilai- nilai sosial yang dibentuk pengarang dari karakter tokoh di dalam novel Maransi. Keempat, konflik-konflik sosial yang dekat dengan adat dan budaya Minangkabau. Novel Maransi menghadirkan konflik mamak dan kemenakan, permasalahan gelar datuk, pewarisan harta pusaka, hubungan kekerabatan matrilineal serta pergeseran peran mamak di dalamnya.

Kisah pada novel Maransi atas pergeseran peran dan fungsi mamak terhadap kemenakan. Perkara-perkara sentral dalam kehidupan masyarakat Minangkabau, seperti tanah pusaka dan pewarisan gelar sako hadir dalam novel. Bahkan, mamak dalam novel melakukan tindakan-tindakan di luar batas wajar saat penyelesaian konflik. Peristiwa seperti ini menjadi tanda tanya jika mamakdi Minangkabau mencerminkan watak dan perilaku yang tergambar pada novel. Sehingga kemenakan, kaum, dan saudara perempuan yang mempunyai hak sebagai limpapeh dan bundo kanduang tidak lagi tampak dalam sosial Minangkabau.

Permasalahan-permasalahan yang dijelaskan di atas dikaji dengan sosiologi sastra.Menurut Ratna (2003: 11) bahwa sosiologi sastra itu meninggkatkan pemahaman terhadap sastra dalam kaitannya dengan masyarakat, menjelaskan bahwa rekaan tidak berlawanan dengan kenyataan. Dengan begitu, karya sastra hadir sebagai gambaran sosial masyarakat yang telah mengalami proses kreatif dan imajinasi. Dengan demikian, novel Maransi menampilkan kondisi sosial masyarakat Minangkabau dengan melihat konflik sosial yang terjadi antara mamak dan kemenakan di 
dalamnya. Selain itu, novel ini menghadirkan kedudukan dan peran mamak dan kemenakan di Minangkabau secara keadaan fakta ke dalam imajinasi pengarangnya.

\section{KERANGKA TEORI DAN METODE}

Secara definitif intensitas sosiologi sastra adalah karya sebagai manifestasiinteraksi sosial. Tuloli (2000: 62) berpendapat bahwa prinsip sosiologi sastra ingin mengaitkan karya sastra, keberadaan karya sastra, serta peranan karya sastra dengan realitas sosial. Sastra tidak dapat dilepaskan dari lembaga-lembaga sosial, agama, politik, keluarga, dan pendidikan, atau sosial budaya. Hutomo (dalam Endraswara) mengatakan bahwa esensi sosiologi sastra adalah memandang karya sastra sebagai produk sosial budaya, dan bukan hasil dari estetik semata.

Karya sastra tidak dapat dipisahkan dari sosial yang membentuknya. Teori sosiologi sastra dalam paradigmanya bukan sebatas mempersoalkan pengarang mampu melahirkan karya, karya bisa lahir atau pembaca terpengaruh dari karyaitu saja. Melainkan karya menjadi objek yang menghubungkannya dengan sosial budaya dan pengarangnya dalam sosial masyarakat yang membentuk karya tersebut.

Ratna (2003: 10) menyatakan bahwa masalah pokok sosiologi sastra adalah karya sastra itu sendiri, karya sebagai aktivitas kreatif dengan ciri yang berbeda-beda. Menggali karya itu sendiri, ada dua indikator yang perlu dipahami, yaitu berkaitan antara bahasa dengan medium dan struktur sosial yang berkaitan dengan masyarakat yang mendukungnya. Dari kedua indikator tersebut, kita dapatmemahami karya sastra dalam sosiologi sastra dari objek material sastranya.

Analisis sosiologi sastra tidak bermaksud untuk mereduksikan hakikat rekaan ke dalam fakta, sebaliknya, sosiologi sastra juga tidak bermaksud untuk melegitimasikan hakikat fakta ke dalam dunia imajinasi. Tujuan sosiologi sastra adalah meningkatkan pemahaman terhadap sastra dalam kaitannya dengan masyarakat, menjelaskan bahwa rekaan tidak berlawanan dengan kenyataan. Karya sastra jelas dikontruksikan secara imajinatif, tetapi kerangka imajinatifnya tidak bisa dipahami di luar kerangka empirisnya. Karya sastra bukan semata-mata gejala individual, tetapi juga gejala sosial ( Ratna, 2003: 11).

Sosiologi sastra melihat sistem sosial, ktitik sosial, pergeseran sosial dansebagainya yang terdapat dalam karya sastra. Talcott Parsons (dalam Ratna, 2003:19)mengatakan bahwa sosiologi sastra itu membicarakan integrasi danketeraturan sosial, pertukaran status peranan, dan proses institusional, misalnyaanalisis interaksi antartokoh dalam konstruksi fakta-fakta sosiokultural.Selain itu, George Simmel dan Ralf Dahrendorf (dalam Ratna, 2003: 19) membicarakaninteraksi sosial, konflik sosial, misalnya analisis koflik tokoh-tokoh, konflik kelas.

Berdasarkan teori di atas, maka penulis menyimpulkan bahwa sosiologi sastra adalah teori yang berfungsi untuk menganalisis karya sastra dengan mempertimbangkan hubungannya dengan sosial, seperti konflik sosial dan interaksi sosial. Dalam penelitian ini digunakan pandangan Ratna tersebut, teori sosiologi sastra ini digunakan untuk menjelaskan bentuk konflik sosial dalam novel Maransi karya A. R. Rizal.

Penelitian ini merupakan penelitian kualitatif dengan menggunakan penafsiran pada data berupa kata-kata tertulis dan lisan berdasarkan pengamatan yang dilakukan. Penelitian kualitatif memberikan perhatian terhadap data 
alamiah,data dalam hubungannya dengan konteks keberadaannya. Dalam sastra, sumber datanya adalah karya dengan bentuk fisik isinya yang berupa naskah, kata-kata, kalimat maupun dialog.

Metode yang digunakan dalam penelitian ini adalah pendekatan sosiologi sastra. Penelitian sosiologi sastra ini adalah untuk mengungkapkan fenomenasosial, kondisi sosial dan konflik sosial yang terdapat pada karya sastra. Data yang diperoleh dalam penelitian ini menggunakan studi kepustakaan. Dengan studi kepustakaan yang dilakukan, maka data yang didapat terbagi atas data primer dan data sekunder. Data primer adalah teks yang bersumber pada novel Maransi. Cara memperolehnya dengan membaca novel dengan teliti, mengumpulkan data dan menggelompokkan data. Dataprimer penelitian ini adalah deskripsi dan dialog yang membangun unsur tokoh dan penokohan, latar, dan alur. Data sekuder berupa buku-buku referensi yang terkait dengan objek penelitian. Data yang diperoleh dipilah dan dipilih yang menunjukkan konflik mamak dan kemenakan. Konflik yang ditemukan dihubungkan dan dianalisis dengan landasan sosiologis peran mamak dan kemenakan di Minangkabau.

\section{HASIL DAN PEMBAHASAN}

Konflik merupakan sesuatu yang dramatik, mengacu pada pertarungan antara dua kekuatan yang seimbang dan menyiratkan adanya aksi dan aksi balasan (Wellek \& Warren dalam Nurgiyantoro, 2010: 122). Konflik menghadirkan gejala sosial yang terjadi antara individu dengan individu lainnya yang mengalami proses perubahan dalam bentuk pertentangan, kekerasan atau bahkan pertikaian di dalam sosial. Hal ini dipicu karena adanya perubahan sosial yang tidak sesuai dengan kehendak individu dalam bermasyarakat.

\section{MAMAK DAN RUMAH GADANG}

Bagi masyarakat Minangkabau, rumah gadang merupakan kebanggaan kaum yang harus dipertahankan keberadaanya. Sehingga pemeliharaan dan pendirian rumah gadang harus disepakati bersama dengan kaum. Rumah gadang menjadi simbol yang kukuh dalam menjalankan peran dan simbol kebesaran dari sebuah kaum.

Dalam novel Maransi terdapat konflik yang saling mencederai antara mamak dan kemenakan dalam pendirian rumah gadang. Bahkan, pendirian rumah gadang ini tidak disepakati bersama dan diambil alih langsung oleh mamak. Mamak berkuasa penuh dalam membangun rumah gadang tanpa mempertimbangkan pembangunan rumah gdang dalam musyawarah kaum. Dalam novel terdapat pada kutipan berikut.

Mandeh menatap sambil mengeryitkan keningnya ke arah Sunur. Perempuan itu seolah-olah meminta pengertian saudara laki-lakinya itu. Laki-laki itu masih segan dengan Mandeh. "Bagiku tak masalah. Tak penting siapa yang akan membangun rumah gadang itu. Bagiku yang utama rumah gadang itu ada sebagai kebanggaan bagi kaum kita."

"Tidak ada rumah gadang. Aku tak hendak membangun rumah gadang." Sunur meradang. Mandeh darahnya berdesir. Cepat-cepat Zakir mendekati Mandeh untuk menenangkan hatinya (Rizal, A. A. 2017: 11).

Dari kutipan di atas diketahui bahwa Sunur menginginkan keputusannya dalam mendirikan rumah gadang dapat disetujui Zakir. Namun, Zakir mengelak untuk tidak membangun rumah gadang. Zakir berkeinginan 
membangun surau demi kepentingan kaum dan orang kampung. Keputusan Zakir tersebut melihat kondisi surau di Batang Maransi tidak layak dijadikan tempat beribadah.

Sunur mengontrol emosi atas kehadiran Mandeh di dalam diskusi tersebut.Ketika Zakir tetap bersikeras dengan keputusannya, Sunur pun meradang hingga membuat Mandeh menjadi cemas. Hal ini membuat Sunur tidak mengingat diri bahwa dirinya sebagai mamak yang disegani oleh kemenakannya di kaumnya.

Konflik penolakan Zakir untuk mendirikan rumah gadang kaum pun menjadi memuncak. Zakir terus membantah karena rumah gadang yang didirikan tersebut tidak berwujud adanya, melainkan membangun awal di atas tanah lapang yang sangat luas. Hal inilah yang membuat Zakir tidak ingin mendirikan rumah gadang kaum. Apalagi Sunur tidak pernah membicarakan bersama kaum - dan hanya menghendaki keinginanya semata. Dalam novel terdapat pada kutipan berikut.

Zakir melihat ke arah yang ditunjuk Sunur. Ia bertanya-tanya, tak ada apa-apa di sana. "Mana? Tak ada apa-apa."

"Oh, halah!" Sunur menepuk tangan. Ia berkelit. Dengan bahasa yang dipermanis, ia berusaha meyakinkan Zakir. "Yah, di sana. Di sana rumah gadang itu akan dibangun."

Dalam permintaan yang datang kepadanya, seharusnya Zakir membangun kembali rumah gadang kaumnya. Kalau membangun kembali, artinya ia hanya meneruskan yang sudah ada. Di tanah lapang itu tak ada apa-apa. Tak ada sisa-sisa yang menunjukkan ada bekas bangunan di sana. "Mana rumah gadang yang akan dibangun itu?"

"Lihat, lihatlah! Tanah lapang itu cukup luas bukan. Lebih setengah hektar. Kita bisa membangun rumah gadang yang besar. Kalau perlu, sembilan ruang."

Bukan itu jawaban yang diinginkan Zakir. Ia bertanya jejak rumah gadang kaumnya di sana. Tapi, Sunur memberikan jawaban yang tak menentu (Rizal, A. A. 2017: 5).

Dari kutipan di atas dapat dilihat bahwa pembangunan rumah gadang yang diinginkan Sunur tidak memikirkan baik-buruk yang akan terjadi. Sunur terus berkeinginan agar rumah gadang dengan luas tanah setengah hektar tersebut dapatdibangun dengan uang pribadi Zakir sendiri. Padahal, dalam adat di Minangkabau untuk mendirikan rumah gadang terlebih dahulu dimufakatkan bersama, lalu diperhitungkan pula biayanya serta dikerjakan bersama-sama kaum dalam gotong royong. Hal ini justru berbanding terbalik dengan tindakan Sunur yang lebih mementingkan kehendak hatinya seorang.

Dalam menjalankan perannya sebagai mamak, Sunur seharusnya mampu mencerminkan dirinya sebagai orang yang didahulukan selangkah, ditinggikan seranting dalam perkara adat. Kehadirannya di dalam kaum menjadi orang yang dapat memperhitungkan baik dan buruk keputusan yang akan ia lakukan. Sama halnya dalam mendirikan rumah gadang kaum tersebut, sewajarnya Sunur merapatkan terlebih dulu bersama kaum tanpa mendahului kehendaknya.

\section{MAMAK DENGAN TANAH PUSAKA}

Harta pusaka kaum berupa tanah diturunkan secara bertali darah menurut garis keturunan ibu. Dalam hal ini, tanah pusaka tidak boleh digadaikan, apalagi diperjual belikan. Sebagai mamak dalam kaum, tentu saja tanah pusaka harus dipertahankan agar tidak diperebutkan kaum demi kepentingan pribadi. Tanah pusaka juga tidak berhak dikuasai oleh satu orang, sebab menjadi milik kaum ataubersama. Kutipan pada novel sebagai berikut.

Jurnal Elektronik WACANA ETNIK - Vol 9 No 1, 2020, (1 - 18) p ISSN 2089-8746, e ISSN 2302-7142 
Beberapa hari lalu, sebuah papan dipancang di atas tanah seberang jembatan. Zakir marah alang kepalang. Sejak kapan pula, Mangkudu memiliki tanah dekat kuburan kaumnya itu. Namun, kemarahan Zakir dihadang Sunur. Mamaknya itu telah bersekutu dengan Mangkudu. Kepada Zakir, Sunur malah meminta dimuluskan persekutuannya itu. "Kau pasti kenal banyak orang-orang kaya di ibukota. Saudagar, pengusaha, atau siapalah yang mau membeli tanah itu dengan harga sepadan." "Aku bukan makelar! Berhentilah, Mamak! Jangan terlongsong langkah menjadi penipu."

Naik darah Sunur ke ubun-ubun mendengar perkataan Zakir. Tapi, ia terlanjur kehilangan nyali. Mana berani laki-laki itu memperlihatkan kemarahannya kepada Zakir. "Kau memang selalu tak senang kepadaku." Setelah itu, Sunur tak pernah lagi berbicara dengan Zakir. Bahkan, laki- laki itu enggan berkunjung kepada Mandeh, saudara perempuannya. Surut hatinya sudah mendarah daging (Rizal, A. A. 2017: 28-29).

Dalam kutipan di atas terlihat bahwa puncak amarah Zakir terjadi ketika Sunur menginginkan tanah pusaka kaum untuk dijual. Apalagi Mangkudu juga memancangkan papan nama di atas tanah kaum di seberang jembatan atas namanya. Kemarahan Zakir akhirnya dilampiaskan kepada Sunur yang menjadi kaki tangan Mangkudu dalam menjual tanah pusaka.

Di Minangkabau, tanah pusaka tidak boleh dialihnamakan. Hal ini justru dilakukan Mangkudu dan Sunur terhadap tanah pusaka kaum. Mereka dalammenjalankan perannya sebagai mamak lebih memilih merusak tatanan adat yang harus dipertahankan. Mereka menggadaikan tanah pusaka yang dimililki kaum dan berusaha merebutnya untuk kepentingan pribadi. Sunur pun berusaha membujuk Zakir (kemenakannya) ikut serta menjual tanah pusaka tersebut. Akan tetapi, Zakir menolak karena Sunur terlalu celaka dalam memperakarakan tanah pusaka yang diwariskan melalui garis ibu—bukan diwariskan kepada laki-laki.

Dalam menjalankan peran mengurus kaum dan rumah tangga, mamak harus mampu memberikan kekuasannya masing-masing. Dalam novel Maransi, ditemukan mamak yang menjual tanah pusaka untuk kepentingan keluarganya, sehingga kaum kerabatnya menjadi tersisihkan. Tanah pusaka yang seharusnya dikelola untuk kelangsungan hidup kaum justru dipergunakannya demi kepentingan keluarganya. Dalam novel tergambarkan pada kutipan berikut.

Mainar menyalahkan Bahrun atas kematian Maril. Tak Cuma itu, Mainar menyalahkan Bahrun atas semua nasib buruk yang menimpanya. Saudara laki-lakinya itu hanya sayang kepada istrinya. Semua tanah kaum dijual untuk menyenangkan istrinya itu. Dibelikan perhiasan, dibuatkan rumah besar, dibelikan kendaraan. Tak ada yang tersisa untuk Mainar dan anak laki-lakinya. "Tak ada yang kau sisakan untukku. Kau biarkan anak laki-lakiku mencari makan di bawah jembatan. Kau biarkan ia mati di sana." (Rizal, A. A. 2017: 79) .

Dari kutipan di atas mengandung makna bahwa dalam menjalankan perannya sebagai mamak di kaumnya, Bahrun bertindak sekehendak hati mengurus tanah pusaka dan mengabaikan kepentingan kaumnya. Sehingga adik perempuanya tidak diberikan kuasa dalam menjaga tanah pusaka sebagai pusako yang diwariskan turun temurun. Dalam tatanan adat, Bahrun hanya diberikan wewenang dalam mengelola tanah pusaka, namun ia lebih leluasa menguasai tanah pusaka sebagai hak miliknya. Bahrun menjual tanah pusaka demi menyenangkan, memperkaya dan memberikan hasil penjualan tanah pusaka kepada anak dan istrinya. 
Harta pusaka juga tidak boleh diperjualbelikan, digadai atau diserahkan kepada keluarga dari seorang mamak. Dalam novel Maransi ditemukan seorang mamak dan saudara perempuannya menjual tanah pusaka demi kepentingannya. Hal ini terdapat pada kutipan berikut.

Sunur sudah mendapatkan pembeli untuk tanah lapang di tepi Batang Maransi. Tapi, itu belum cukup baginya. Sunur berniat menjual rumah batu Mandeh. Keinginan Sunur itu ditentang keras oleh Zakir.

"Rumah batu itu aku yang membuatnya dengan uang hasil jerih- payahku sendiri. Rumah itu untuk Mandeh, bukan untuk diperjualbelikan." Sunur tak berniat mendapatkan uang dari rumah batu Mandeh. Ia hendak menjual tanah di bawah rumah itu. Menjual tanah lebih besar untungnya. Harganya bisa dipatok sekehendak hati. "Aku takkan menjual rumah batu itu. Yang kugadaikan tanahnya. Tanah itu milik kaum." "Mamak tak punya hak atas tanah kaum itu."

"Aku seorang memang tidak. Tapi, hakku bersama etek-etekmu. Mereka sudah setuju denganku." Sunur menebar senyum kemenangan kepada Zakir.

"Aku meminta kuasaku atas tanah kaum." Rodiah menyela.

Pikirannya sudah seiring sejalan dengan Sunur.

"Tidak semuanya!" Zakir tak melihat Etek Ros. Saudara perempuan Mandeh itu paling melarat hidupnya. Ia tak dianggap.

"Etekmu itu pasti setuju!" Sunur sangat percaya diri dengan ucapannya. Diperlihatkan saja uang segenggam, saudaranya itu pasti akan menurut.

Zakir kehilangan kuasa di hadapan Sunur. Ia bukanlah apa-apa di hadapan mamak dan etek-eteknya.

"Terserah Mamak! Yang jelas, Mamak harus menjualnya kepadaku."

Menggerutu mulut Sunur. "Memang lihai kau."

Bayangan mendapatkan untung besar, buya sudah. Bagaimana bisa Sunur meminta harga berlipatlipat kepada kemenakannya sendiri (Rizal, A. A. 2017: 192-193).

Dari kutipan di atas memaparkan kejanggalan yang terjadi di Minangkabau, di mana seorang mamak berusaha menjual tanah kaum yang didirikan bangunan di atasnya. Ada keinginan dan ambisi yang kuat bagi seorang mamak dalam mendapatkan keuntungan dari tanah kaum yang dijualnya. Apalagi,seorang mamak turut menjual tanah kaum kepada kemenakannya sendiri. Bukan hanya itu, saudara perempuan (etek) bagi seorang anak dalam kaum seharusnya ikut menjaga dan mempertahankan tanah kaum, namun mereka ikut membantu saudara laki-lakinya untuk menjual tanah kaum tersebut. Sehingga mereka tidak melihat kepentingan kaum atas tanah pusaka yang dikelola dan diwariskan nantinya.

Munculnya konflik tersebut dalam novel Maransi menghadirkan gejolak yang besar di Minangkabau, bahwa perilaku seperti itu memunculkan mamak- mamak yang berkeinginan besar dalam menguasai tanah pusaka kaum. Mamak dengan mudahnya ikut campur dalam menggadaikan tanah pusaka yang tidak diberikan kuasanya padanya.

\section{MAMAK DENGAN HARGA DIRI KAUM}

Dalam adat Minangkabau dikenal dengan istilah mamak rumah. Mamak rumah ialah laki-laki yang dituakan menjadi pemimpin di dalam rumah gadang kemenakannya, akan tetapi tidak mencampuri kehidupan kemenakan. Bagi orang pendatang tentu saja harus mengangkat mamak rumah dari seorang laki-laki yang dituakan di suatu tempat dalam menjalankan peran sebagai mamak baginya. Mamak rumah ini berfungsi sebagai orang yang bertanggung jawab atas rumah tangga kemenakan. Dalam novel terdapat dalam kutipan berikut. 
Syarat mengangkat mamak rumah adalah digelar terlebih dahulu sebuah perjamuan. Bagi Ainun, perjamuan itu tak masalah. Zainal bisa menyediakan uangnya. Tak perlu mengundang banyak orang, cukup orang-orang di sekitar saja. Sunur tak mempermasalahkan itu. Mau satu, dua atau tiga orang yang diundang dalam perjamuan, yang penting baginya, martabat mengangkat dirinya sebagai mamak rumah tak berkurang. Martabat itu bagi Sunur diukurnya dari persyaratan yang yang mesti diberikan Ainun.

"Kau tahu, semakin banyak pemberianmu, maka semakin besar pula kau menghargaiku."

Entah persyaratan itu ada, atau Sunur saja yang membuat-buatnya saja, permintaan sejumlah uang membuat Ainun risau. Zainal sudah ingin melampiaskan amarahnya kepada Sunur, laki-laki itu memerasanya. Namun, Ainun mencegah. Tak elok mengumbar amarah bagi diri sebagai pendatang. "Limapuluh juta! Dari mana mendapatkan uang sebanyak itu." Ainun memelas kepada Mandeh. Kabar Sunur meminta uang berpuluh juta disampaikan Mandeh kepada Zakir.

"Tak pantas Mamak memperjualbelikan adat bermamak rumah itu. Malu kaum kita!" Tak pernah Zakir marah kepada Sunur. Durhaka kemenakan namanya jika menghardik mamaknya. Tapi, Sunur tak cukup kalau cuma dihardik.

"Aku tak meminta. Mereka bisa mengukur sendiri seberapa pantasnya menjadi mamak rumah. Kau pikir, jadi mamak itu gampang? Aku yang bertanggung jawab penuh terhadap mereka." Sunur menepuk dada (Rizal, A. A. 2017: 56-57).

Dari kutipan terlihat bahwa Sunur menginginkan Ainun mengangkatnya sebagai mamak rumah, sebab dirinya sebagai orang pendatang di Maransi. Hal ini dilakukan Sunur agar dirinya mempunyai tanggung jawab terhadap rumah tangga Ainun. Akan tetapi, keinginan Sunur mengangkat dirinya sebagai mamak rumah justru berbanding terbalik dengan persyaratan yang sangat merugikan Ainun. Pengangkatan Sunur sebagai mamak rumah harus diperhitungkan dengan jumlah uang yang begitu banyak, membuat Ainun dan Zainal merasa dirugikan. Mendengar pembicaraan pengangakatan Sunur sebagai mamak rumah dari Mandeh, Zakir pun menentang Sunur untuk tidak memperjualbelikan adat bermamak rumah. Sebab, dalam adat di Minangkabau — tidak baik bagi suatu kaum memperjualkanbelikan adat bermamak rumah bagi pendatang dengan cara memerasnya. Mendengar perkataan Zakir, Sunur malah membantah bahwa menjadi mamak rumah itu tidak gampang dan ditambah dengan menepuk dada tanda kebenaran yang telah diperbuatnya.

Dalam perjamuan menggelar adat bermamak rumah. Kembali terjadi konflik antara Sunur dan Zakir yang masih memperhitungkan uang pemberian dalam pengangkatan Sunur sebagai mamak rumah. Pada novel terdapat di kutipan berikut.

Sunur menghela napas. Amarah mengalir ke ubun-ubun kepalanya. Sekali lagi, ia melirik ke arah Ainun. Ainun kembali meneruskannya kepada Zainal. Zakir menangkap gelagat Zainal yang tak biasa. Ia pun angkat bicara."Aku, Mamak! Syaratnya ada padaku." Zakir berbicara kepada Sunur. Sunur tergagap. "Oh, ya! Itu, sudah sepakat limapuluh." Sunur mengangkat satu tangannya, memperlihatkan lima jari yang terbuka kepada Zakir.

Zakir mengangguk. "Seratus!" Zakir membalas dengan memperlihatkan seluruh jarinya kepada Sunur.

Sunur menelan ludah. Kemenakannya itu telah membuang mukanya dalam perjamuan. "Ya, ya! Kalau begitu, Ainun sudah sah jadi anak-kemenakan kaum kita. Akulah mamaknya. Anak dipangku, kemenakan dibimbing. Itulah tanggung jawabku." Sunur menepuk dada. Terasa sesak di sana (Rizal, A. A. 2017: 57-58).

Pada kutipan di atas terlihat bahwa Zakir menangkap perilaku Zainal dan Ainun yang tidak biasanya. Zakir pun dengan suara yang lantang membayar uang pemberian pengangkatan mamak rumah terhadap Sunur. Zakir 
membayar nominal yang lebih mahal dari uang yang diminta Sunur pada Ainun. Sunur pun tergagap dan menepuk dadanya sebagai konflik yang ada di dalam dirinya.

Konflik dari kedua kutipan di atas menunjukkan pertikaian antara mamak dan kemenakan dalam pemberian uang pengangkatan mamak rumah. Sunur dengan perilakunya memeras Ainun dan Zainal atas pengakatan tersebut. Makanya, melihat perangai Sunur membuat Zakir merasa terhutangi akibat ulah Sunur yang memperjualbelikan adat bermamak rumah yang merusak harga diri kaum. Puncak konfliknya terjadi ketika Zakir memberikan uang seratus juta untukmembayar Sunur dalam pengangkatan diri sebagai mamak rumah. Tujuannya supaya Sunur merasa tersindir atas pemberian uang pengangkatan dirinya.

Selain itu, perselisihan mamak dengan kemenakan juga terjadi ketika kemenakan menentang kehendak mamak, atau justru membuat malu mamaknya dimata kaum. Dalam novel terdapat pada kutipan berikut.

"Soal pilihanku tak ada masalah. Aku bisa meminangnya di kampung, bisa pula membawanya kawin lari." Farlan terdiam sesaat. "Masalahnya, aku bertengkar dengan mamakku."

Pasti Sunur yang memulai gara-gara. Zakir memaklumi masalah yang dihadapi Farlan dengan mamaknya itu. "Kau paham sendirilah tabiat mamakmu itu. Biasa saja bertikai dengannya. Jangan terlalu diambil hati.:"

"Aku memukulnya. Ia melaporkanku ke polisi!"

Zakir iba melihat Farlan. Tapi, di belakang itu ia bisa tersenyum dengan nasib Sunur. Akhirnya, laki-laki itu kena batunya juga. "Tenang saja kau di sini. Nanti, aku akan menghubungi mamakmamak di kampung.” (Rizal, A. A. 2017: 34).

Dari kutipan tersebut dapat terlihat bahwa pertikaian antara Farlan terjadi akibat pemukulan yang dilakukannya terhadap mamaknya. Ketika Farlan mengadu kepada Zakir—pun merasa puas dan tersenyum karena Sunur mendapatkan ganjaran akibat ulahnya sendiri. Keberadaan ini tentu sangat baik bagi Zakir melihat nasib Sunur yang akhirnya menerima ganjarannya sendiri.

Pemukulan terhadap Sunur ini terjadi karena Farlan tidak mendapatkan restu untuk menikahi perempuan Nias yang pantang bagi mamak di Maransi. Sunur dengan nada meningginya melampiaskan kemarahannya kepada Farlan yang tidak tahu adat dalam mengukur calon isttinya tersebut. Penggambaran sikapini dijelaskan pengarang melalui dialog sebagai berikut.

Pertanyaan Sunur tak terjawab. Farlan langsung menyergahnya. "Dia punya ayah. Ayahnya ada di kampung."

"Di mana kampungmu?" Sunur penuh selidik. "Nias! Tapi, ia dibesarkan di sini."

Berubah masam muka Sunur. Ia tak menyembunyikannya di hadapan Farlan. "Tak tahu malu kau! Dia perempuan tak beradat." Sunur berbisik kepada Farlan.

Terhenyak Farlan mendengar perkataan mamaknya itu. Laki-laki itu seperti melemparkan arang berkarung-karung ke wajahnya. "Mamak yang membuatku malu!" Amarah Farlan memuncak.

"Tak usah kau meminta restuku. Haram bagiku memberikannya."

Sunur meninggalkan Farlan di balik pintu. Farlan menumpahkan amarah di daun pintu itu. Amarahnya teramat kuat sehingga sikutnya terpental. Tepat di wajah Sunur.

“Kemenakan celaka!” Sunur memaki dengan sumpah-serapah (Rizal, A. A. 2017: 7).

Dari kutipan di atas tampak bahwa Sunur tidak merestui Farlan dengan calon istri yang dihadapkan kepadanya. Bagi Sunur, orang Nias yang dibesarkan di Maransi merupakan perempuan yang tidak beradat. Makanya, 
Farlan merasa tersinggung dan tersulut amarahnya dengan memaki Sunur. Kondisi seperti ini menimbulkan konflik yang berat bagi keduanya. Sebagai mamak yang harus dijunjung tinggi oleh adat dan mamak haruslah menjalankan perannya dalam memilih atau memilah calon istri bagi kemenakannya. Akan tetapi, Sunur terlalu menempelak Farlan dengan kata-kata kasar yang memancing kemarahannya kepada Sunur.

Dengan kemarahan tersebutlah, Farlan akhirnya mementalkan pintu sehingga mengenai wajah Sunur. Hal ini menandai kemarahan yang memuncak dan merusak harga diri Sunur sebagai mamak yang harus dihormati dan disegani. Permasalahan ini diperpanjang Sunur untuk melaporkannya ke polisi supaya harga dirinya tidak tercoreng di mata orang kampung. Penggambaran sikap ini dapat kita lihat pada dialog berikut ini.

Kejadian sore itu cepat menyebar ke mana-mana. Orang-orang kampung mempergunjingkan setelah Sunur melapor ke kantor polisi. Sunur bahkan melaporkan Zakir karena telah menyembunyikan Farlan.

"Aku kan saudara laki-lakinya. Baik-buruk saudaraku, pastilah aku akan membelanya. Tapi, mengapa Mamak sampai hati melaporkanku pula?"

Sunur tergagap. Ia tak pernah berniat berseberangan apalagi bertikai dengan Zakir. "Bukan, bukan aku! Bahrun dan datuk-datuk lain yang melaporkan.”

Zakir menjadi bingung dengan perkataan Sunur. Mengapa Sunur membawa-bawa dirinya berperkara dengan datuk-datuk di Maransi. "Aku tak ada masalah dengan datuk-datuk itu."

"Kau bersama Farlan. Bersama saudara laki-lakimu itu ada Kutar dan beberapa anak Maransi. Mereka yang dilaporkan karena berpekara dengan datuk-datuk di sini."

Farlan tak hanya membawa masalah dirinya ke ibukota. Masalah anak-kemenakan di Maransi, kini sampai kepada Zakir. Jauh di perantauan, perkara-perkara di kampung halaman terus saja menyeretnyeret dirinya (Rizal, A. A. 2017: 38).

Kutipan sebelumnya menggambarkan suatu sikap yang tidak lagi mencerminkan hubungan erat antara mamak dan kemenakan. Sunur dengan gampangnya melaporkan Farlan yang telah menjatuhkan harga dirinya. Begitu juga melaporkan Zakir yang menyembunyikan Farlan di ibukota. Sebagai mamak,seharusnya Sunur memberikan ganjaran yang setimpal terhadap Farlan yang telah mengenai kepalanya, bukan melaporkan ke polisi. Perselisihan perkara ini dimunculkan ketika Sunur mengatakan bahwa datuk-datuk di Maransilah yang melaporkannya dan hal ini dilakukan untuk menyelamatkan harga diri kaumnya.

Perkara ini diperpanjang ketika Sunur membicarakannya kepada datuk- datuk lainnya di Maransi. Sehingga, cerita Sunur yang dianggap biasa tersebut digadang-gadangkan tanpa adanya jalan kekeluargaan sebagai kaum yang beradat,dan sebagaimana digambarkan pada kutipan berikut ini.

“Anak-anak itu kurang ajar! Tak perlu kau melindunginya." Sunur menyampaikan sakit hati Bahrun kepada Zakir.

"Buah tak jauh jatuhnya dari pohon. Tak ada kemenakan yang terjatuh, kalaulah bukan karena tongkat yang membawa rebah.” Zakir menapik kemarahan Bahrun di muka Sunur.

Pertikaian tak berawal itu berujung juga di kantor polisi. Zakir memenuhi panggilan polisi perihal anak-anak muda Maransi yang datang kepadanya ke ibukota. Mereka dilaporkan oleh Sunur, Bahrun, dan datuk- datuk lainnya. Bukan perkara besar. Hanya perihal harga diri membuat perkara itu seperti tak bisa terselesaikan. Polisi menawarkan jalan damai. Itulah sebenarnya yang dikehendaki Zakir.

"Kalah jadi arang. Kalaupun menang, jadi abu."

Bahrun tak senang dengan perkataan Zakir. Laki-laki itu takut kalah bijaksana di hadapan Zakir. "Mereka itu anak-anak tak tahu diuntung. Biarlah penjara mengajarkan mereka." 
"Mereka pasti telah mendapat banyak pelajaran. Bukan penjara tempat belajar mereka. Datuk pasti lebih tahu bagaimana mengajarkan anak-kemenakan itu."

Kata-kata Bahrun berbalik kepadanya. Tapi, laki-laki itu tak hendak kalah di hadapan Zakir. "Perangai mereka itu keterlaluan, malu kaum, malu kampung dibuatnya."

"Mereka kan anak-kemenakan Maransi juga. Kalau mereka dipenjara, kampung ini juga yang terbawa malu."

"Biarkan saja! Anak-anak itu sudah tak tahu malu." "Datuk sebagai mamaknya juga akan terbawa malu."

Bahrun tak senang Zakir terus membantahnya. "Harga diri datuk tetaplah yang paling utama. Anakkemenakan mestilah menjunjungnya."

"Harga diri mana yang Datuk maksud?"

"Datuk-datuk di Maransi!" Bahrun sangat bersemangat. Sampai- sampai, tak sadar ia menepuk dadanya sendiri.

"Bukankah itu untuk diri Datuk sendiri?" Zakir menyindir. Bahrun tersungut hidungnya. Ia telah melepaskan harga dirinya sendiri, di depan kantor polisi, di hadapan Zakir (Rizal, A. A. 2017: 139140).

Dari kutipan di atas terlihat selisih paham antara Sunur dan Zakir yang terus memperkarakan permasalahan Farlan ke ranah adat. Hal ini ditujukan pula kepada Bahrun sebagai datuk yang memegang peran dalam hukum dan perundang-undangan di Maransi. Dengan ujaran kebencian yang diucapkan Sunurmenyimbolkan kebengisan, kemarahan serta ketidaksukaannya terhadap Farlan sebagai kemenakannya yang telah berani mencoreng arang di kepalanya. Maka dari itulah, Zakir pun membela diri bahwa perangai kemenakan diturunkan dari mamaknya. Makanya, sikap Farlan yang melawan kepada Sunur ialah sikap yang diturunkan oleh Sunur seabgai mamaknya.

Perihal harga diri yang diagung-agungkan Sunur dalam membela diri inilah yang sangat disayangkan Zakir. Sunur tetap bersikeras untuk menggugat Farlan dan Zakir untuk dipenjara. Bagi Sunur, jika mereka berdua dipenjarahanya diri kemenakannya saja yang tercoreng, bukan pada dirinya yang disangkut-pautkan pada harga diri kaum. Padahal, kemarahan Sunur yang terbilang biasa tersebut dapat diselesaikan dengan jalan damai.

\section{MAMAK DENGAN KEMENAKAN}

Falsafah adat Minangkabau yang mengatakan anak dipangku kemenakan dibimbing harus dipahami setiap laki-laki dewasa di Minangkabau yang berkedudukan sebagai mamak. Anak bagi seorang ayah memangku dalam menjalankan kehidupan, sebab ia akan mendapatkan bimbingan dari seorangmamak di kaumnya. Hal ini justru menjadi polemik di dalam novel Maransi yang menimbulkan konflik di antara mamak dan kemenakan. Dalam novel terdapat pada kutipan berikut.

.... Ketika Sunur menyampaikan kehendaknya kepada Mandeh, perempuan itu langsung membuat titah kepada Zakir. "Kau bimbing baik- baik adik laki-lakimu itu. Kalau gagal di rantau, ia akan menjadi malu bagi kaummu di kampung."

Zakir sudah enggan berurusan dengan segala hal yang berhubungan dengan Sunur. Tidak dengan mamaknya itu, tidak dengan segala sesuatu yang berkaitan dengan laki-laki itu, termasuk dengan darah- dagingnya. Tapi, tak ada kuasa Zakir menolak perintah Mandeh. "Mandeh tenang saja." (Rizal, A. A. 2017: 60).

Dari kutipan di atas terlihat adanya konflik pada Zakir yang keberatan membimbing dan mengurus anak dari Sunur. Zakir tidak dapat menolak membimbing anak Sunur dan memberikan nasihat kepadanya karena permintaan Mandeh. Keberadaan Sunur di sini tidak mencerminkan perannya sebagai ayah bagi anaknya yang seharusnya 
memangku anaknya, melainkan menyerahkan perannya kepada kemenakannya sendiri, yakni Zakir. Makanya, Zakir tidak ingin tersangkut paut dengan Sunur dan Sulam dalam permasalahan ini.

Konflik ini menimbulkan peran seorang mamak dalam membimbing dan menunjuk ajari seorang kemenakan sebagai tanggung jawabnya. Dalam peran dan kedudukannya, mamak memegang tampuk tinggi di rumah gadang sebagai orang yang berhak memberikan arahan serta pengajaran terhadap sosial masyarakatkemenakannya. Sebab, seorang ayah hanyalah abu di ateh tunggua (abu di atas tunggul) di rumah gadang dan berperan sebagai urang sumando (orang semenda).

Mamak di Minangkabau memberikan pengajaran dan arahan kepada kemanakannya. Dalam novel terjadi konflik antara kemenakan yang melampiaskan kemarahannya terhadap mamak yang terlalu memaksa kemenakannya untuk menerima proposal dan mengambil keuntungannya di sana. Dalam novel terdapat dalam kutipan berikut.

Zakir menyampaikan pesan kepada Sunur. Ia tak senang dengan bertubi-tubi proposal yang sampai kepadanya melalui mamaknya itu. "Kalau Mamak berkirim proposal, yang sepatut-patutnya sajalah."

Mendengar perkataan Zakir, justru Sunur merasa lebih tak senang. "Aku ak mengambil keuntungan dari proposal itu. Mengapa kesal kau timpakan kepadaku?"

Zakir menjadi tak enak hati. Mamaknya itu bisa pula merasa tersinggung. "Aku tak menyalahkan Mamak. Tapi, aku minta Mamak pandai-pandailah menimbang-nimbang. Tak semua permintaan sumbangan bisa aku penuhi. Perhitungkan jugalah kemampuanku. Di rantau, aku bukan apaapalah." (Rizal, A. A. 2017: 71).

Dari kutipan di atas terlihat bahwa Zakir menyampaikan amarahnya ke Sunur karena telah mengirim berulang kali proposal kepadanya. Zakir tentu saja tidak memiliki harta berlimpah di rantau pada setiap proposal yang didatangkan kepadanya. Hal ini membuat Zakir tersulut amarah untuk menimbang-nimbang proposal dari mamaknya tadi. Akan tetapi, Sunur malah berkilah bahwa proposal yang dikirimkan tersebut tidak diambilnya keuntungan dari sana. Zakir pun merasa bahwa Sunur tidak mampu berpandai-pandai dalam hal meminta sumbangan kepadanya yang terlalu berlebihan dan tidak sewajarnya.

Di Minangkabau, tentu seorang mamak harus menjaga nama baik kemenakannya. Seorang kemenakan pun juga harus menjaga nama baik mamaknya. Dalam novel terdapat kesalahpahaman antara Sunur dan Zakir yang membuat konflik baru, seperti pada kutipan berikut.

Kring, kring, kring. Sunur menelepon dari telepon rumah. "Apa kirimanku sudah sampai?" Zakir tergagap. Ia tak mengerti pertanyaan Sunur. "Kiriman apa?" Tak mungkin Sunur mengirimkan rendang dari kampung. Zakir mulai gusar. Setiap mamaknya itu berkirim, yang selalu datang pastilah masalah. "Kau terlambat membalas. Orang-orang di kampung terlanjur mempergunjingkanmu. Jangan kirim arang di muka kaummu."

Perkataan Sunur sungguh memerahkan telinga. Zakir mencari-cari apa kesalahannya. Disibak-sibak seisi meja dekat telepon rumah. Ada banyak tumpukkan kertas di sana. Sebuah amplop besar yang belum terbuka terselip di tumpukan paling bawah. Dikirimkan sepekan yang lalu. Zakir lupa membukanya (Rizal, A. A. 2017: 74).

Dari kutipan tersebut terlihat bahwa Sunur menelepon Zakir untuk mengabari permasalahan yang terjadi di kampungnya. Hal ini terjadi karena Zakir mengabaikan setiap kiriman yang ditujukan kepadanya. Zakir melakukannya karena setiap kiriman yang didatangkan kepadanya pasti menuai permasalahan yang disangkutpautkan kepadanya.

Jurnal Elektronik WACANA ETNIK - Vol 9 No 1, 2020, (1 - 18) p ISSN 2089-8746, e ISSN 2302-7142 
Sunur marah ketika Zakir tidak menerima kiriman tersebut. Sunur pun mengatakan agar Zakir tidak membuatnya malu kaumdi keningnya. Dari perkataan Sunur tadilah, membuat Zakir merasa tersinggung dan berusaha mencari kiriman tersebut.

Konflik yang terjadi pada kutipan tersebut menyatakan bahwa kemarahan Sunur sebagai mamak di kampung terjadi ketika Zakir mengabaikan kiriman yang ditujukan kepadanya. Kejadian ini diperkuat oleh ketidakinginan Zakir yang berurusan dengan Sunur yang terus mendatangkan masalah baginya. Apalagi, hal ini ditambah ketika Sunur terus mendesak Zakir untuk berbuat lebih terhadap kampung halamanya. Padahal, semuanya telah dilakukan Zakir, namun hanya bernilai sia-sia.

Dalam menjalankan perannya di Minangkabau, mamak dan kemenakan tentu harus sejalan dan sepaham, serta searah sepemikiran. Mamak tahu danpaham dengan jalan pikiran kemenakannya, dan begitu pun dengan kemenakan yang tahu cara dalam bersikap. Akan tetapi, dewasa ini banyak terjadi sindir menyindir antara mamak dan kemenakan dengan tujuan menjatuhkan harga diri satu di antaranya. Dalam novel terdapat dalam kutipan berikut.

Tak terhitung berapa biaya yang dihabiskan untuk membangun rumah gadang. Sunur menerima uang dari Zulkarnain berapa pun yang dimintanya. Ia mengira, uang laki-laki itu tak berseri. Pastilah kekayaannya mengalahkan Zakir. "Kau tak ada apa-apanya dibandingkan dia, Zakir." Sunur menyindir kemenakannya. Masih belum hilang kesal hati Sunur karena Zakir tak jadi membangun rumah gadang untuk kaumnya.

"Tak apalah! Aku kan selalu kalah di mata Mamak." Zakir balas menyindir Sunur. Tapi, ia tak sungguh-sungguh. Ia hanya ingin melihat sebentar wajah mamaknya itu berubah kusut. Dari tadi, laki-laki itu terlalu berbesar hati. Zakir khawatir mamaknya itu menjadi lupa diri (Rizal, A. A. 2017: 129).

Dari kutipan di atas terlihat bahwa sebagai mamak-Sunur menyindir Zakir karena tidak memberikan apa yang diinginkannya, termasuk mendirikan rumah gadang kaum yang ingin dikuasainya. Sunur terus menyindir Zakir dengan menggadang-gadangkan pemberian Zulkarnain atas pengangkatan gelar dattukyang diterimanya. Makanya, Sunur menyindir Zakir dengan menyanjung- nyanjung Zulkarnain yang mampu memberikan uang yang tak sebanding dengan pemberian Zakir. Berangkat dari sanalah, Zakir pun membalas sindiran tersebut. Zakir menuai sindirannya dengan mengatakan bahwa apapun yang dilakukannya akan tetap salah di mata Sunur. Hal ini terbukti ketika Zakir membantu kampung halamannya seperti memperbaiki Batang Maransi, pembangunan pusatpemerintahan di Maransi dan sebagainya. Jika terjadi kekacauan—pastilah Zakir yang disalahkan.

Pertikaian yang diakibatkan oleh sikap saling menyindir ini tentu saja membuatnya malu. Sebab yang dipermasalahkan oleh Sunur ketika Zakir tidak memberikan apa yang diinginkannya. Begitu juga yang dirasakan Zakir dalam membantu Sunur — mamaknya yang terus disalahkan dalam sikapnya.

Mamak menjadi panutan bagi kemenakan dan anaknya dalam menjalankanperannya di kaumnya. Jika mamak tidak mampu membimbing kemenakannya, berarti ada nilai-nilai moral dan etika yang telah diabaikan mamak pada proses pembimbingan tersebut. Mamak telah merusak tatanan adat yang dijunjung tinggi masyarakat Minangkabau di kehidupan. Maka dari itulan, peran mamak di Minangkabau justru lebih berat daripada peran ayah. Hal ini tergambarkan dalam kutipan berikut ini.

Jurnal Elektronik WACANA ETNIK - Vol 9 No 1, 2020, (1 - 18) p ISSN 2089-8746, e ISSN 2302-7142 
Kalau sudah membawa-bawa utusan adat bermamak dan berkemenakan, Zakir tak bisa membantah Sunur. Mamak itu selalu hebat, jadi junjungan. Begitulah kemenakan harus selalu melihatnya. "Aku tahu, Mamak orang yang bijaksana. Anggap saja perbuatan Farlan itu sebagai kenakalan kecil. Maklum, umurnya masih muda. Mudah salah langkah. Ia masih banyak butuh bimbingan dan diarahkan."

Sunur tahu, Zakir tak pernah sepaham dengannya. Tapi, cara kemenakannya itu menyindir, membuat ia tak enak hati. Terbaca ia maksud perkataan Zakir yang malah menyalahkannya. "Salahku tak bisa membimbing kemenakanku. Puas kau?" Suara Sunur makin meninggi. Ia tak marah. Zakir tahu, mamaknya itu mudah tersinggung (Rizal, A. A. 2017: 136).

Kutipan di atas menggambarkan kesalahan Sunur dalam membimbing kemenakannya. Sunur terlalu menuruti kehendak hatinya dalam mengurus kaum. Setiap menghadirkan dirinya dalam keputusan-keputusan kaum, Sunur bertindak sebagai mamak yang mementingkan kehendaknya semata. Dengan kenalakan yang dilakukan Farlan dalam pertikaiannya dengan Sunur mampu menjadi ganjaran terhadap peran Sunur sebagai mamak yang membimbing kemenakan.

Tali kekerabatan antara mamak dan kemenakan sangatlah erat. Mamak mempunyai kewajiban dalam membimbing, menunjuk ajari, memberikan petuah dan pengetahuan dalam hidup kepada kemenakannya. Mamak bertanggung jawab membela kemenakannya walau dalam keadaan apa pun. Bukan menghindar atau memutuskan tali kekerabatannya dengan kemenakannya. Jika kemenakan mempunyai kesalahan, tentu semuanya berpusat pada mamaknya yang berhak menjalankan perannya sebagai pembimbing kemenakan. Dalam novel terdapat pemutusan tali darah dengan kemenakan yang mengalami konflik antara Sunur dan Zakir, sebagai berikut.

"Dia harus pergi dari Maransi! Tak ada lagi haknya sebagai perempuan. Kaum dan seisi kampung sudah mengusirnya. Jangankan itu, bumi saja menolaknya." Sunur menumpahkan kemarahan kepada Zakir. Laki-laki itu ikut-ikutan pula menimpakan semua kesalahan kepada Zakir.

Zakir tahu, Sunur hanya berpikir ingin lari dari tanggung jawab. Ia tak setuju dengan pikiran mamaknya itu. "Tak usah diusir. Ia akan pergi dengan sendirinya. Kalau ia tak lagi di sini, kita benar-benar akan kehilangan dirinya."

"Sudah hilang semua harkatnya. Ia bukan lagi anak-kemenakan, ia bukan lagi anggota kaum, bahkan sebagai manusia, ia tak lagi diakui."

"Bagaimanapun, ia tetap adik perempuanku. Tali darah tak bisa terhapuskan."

"Tali itu sudah putus! Kau sudah kehilangan seorang saudara perempuan. biarlah takdirnya begitu. Biarlah hilang nila setitik, asal tak rusak susu sebelanga."

Sunur tak pernah merasa sebagai mamak di kaumnya. Ia tak pernah peduli dengan anakkemenakannya. Hal yang paling dipedulikannya adalah tentang dirinya sendiri. Zakir menghela napas dalam-dalam melihat ulah mamaknya itu. "Mamak tak marah kepada Aliyah. Mamak hanya marah kepada aib yang telah dicorengkannya." (Rizal, A. A. 2017: 145).

Dari dialog tersebut terlihat bahwa Sunur mengeluarkan amarahnya kepada Zakir karena ulah kemenakan perempuannya. Aliyah yang semula hendak dinikahkan dengan Janir harus digagalkan oleh Zakir untuk mengekuliahkan Aliyah di Jawa. Alasan ini dilakukan Zakir agar Aliyah—yang masing remaja belia bisa mengenyam pendidikan yang lebih tinggi dan tidak menikah dengan datuk tua bernama Janir. Hal inilah membuat Sunur marah dan menumpahkannya kepada Zakir. Selepas pulang ke kampung, Aliyah berubah perangai dengan mengikuti gaya orang kota dan meninggalkan jati dirinya sebagai perempuan Minang. 
Sunur memunculkan pertikaian ini dengan Zakir supaya semua kekesalannya tertumpah. Sehingga Sunur pun menghapus Aliyah dari suku dan mengusirnya dari kampung halaman. Dilakukannya sikap seperti oleh Sunur agar dirinya tidak ikut tercoreng namanya di mata orang kampung. Sebab, hukum masyarakat Minangkabau berlaku jika kemenakannya berperangai tidak baik pastiyang akan disalahkan ialah mamaknya, bukan ayah dari si anak.

Dari konflik tersebut dapat ditemukan bahwa kegagalan dalam membimbing kemenakan bukan jatuh kepada Zakir. Sebab, peran yang dipikul Zakir hanya sebagai kakak laki-laki. sedangkan dalam Minangkabau sendiri— yang bertanggung jawab dalam membina dan membimbing kemenakan ialah mamak, yakni Sunur. Sunur pun dalam kutipan di atas juga tidak menampilkan dirinya sebagai mamak yang bertanggung jawab. Ia hanya mementingkan dirinya dan lebih memedulikan kaum jika berbuah keuntungan kepadanya.

Sikap tersebut tentu saja menampilkan konflik antara Sunur sebagai mamak dan Zakir sebagai kemenakan yang memperkarakan kemenakan perempuannya. Dalam menjalakan perannya, Sunur tentu harus memahami dirinya dalam memberikan bimbingan dari perangai berperilaku dan pantangan bagi perempuan Minangkabau kepada kemenakan perempuannya. Dengan mengusir kemenakan perempuan dan memutuskan tali darah tentu juga akan merusak tatanan kaum.

Di Minangkabau, pantang bagi seorang mamak ikut campur dalam urusan rumah tangga kemenakannya. Mamak tidak memiliki kedudukan khusus terhadap rumah tangga kemenakannya dan mengatur kehidupan kemenakannya tersebut. Setelah kemenakan berumah, hanya dapat memberikan pengetahuan berumah tangga, serta segala hal yang akan dijalankan dalam berkehidupan berumah tangga. Akan tetapi, dalam merusak dan mengatur dengan peran mamak — ia tidakmempunyai kekuasaan lebih. Dalam novel, terdapat kutipan berikut ini.

Ketika masalah rumah tangga Zakir sampai kepada Sunur, laki-laki itu malah berkomentar yang macam-macam. "Itulah mudaratnya beristri gadis seberang. Aku kan sudah melarangmu. Kalau kau minta, akan aku carikan gadis di kampung yang paling baik. Kau takkan menyesal mendapatkannya."

"Aku tak pernah menyesal. Tak perlu Mamak berulah dengan urusan rumah tanggaku." Zakir tak senang dengan komentar Sunur. Mamaknya itu pandai bermain di air keruh. Masalah kecil, kalau sampai ke tangan laki-laki itu, bisa berubah jadi bencana. Kusut bisa dibuatnya makin berkerut (Rizal, A. A. 2017: 179-180).

Kutipan di atas menggambarkan bahwa Sunur melakukan tindakan- tindakan yang tidak sepatutnya diperbuat oleh mamak di Minangkabau. Dalam menjalankan perannya, mamak tidak mempunyai kekuasaan dan wewenang lebih dalam mengatur rumah tangga Zakir. Dengan berkomentar tidak sepatutnya telah mencerminkan mamak yang tidak tahu sopan santun. Tidak patut jika seorang mamak merusak rumah tangga kemenakan dan berbuat di luar kehendak kemenakannya.

\section{MAMAK DENGAN GELAR SAKO}

Sepanjang adat Minangakabau gelar sako yang diwariskan turun-temurun dari ninik ke mamak, mamak ke kemenakan tidak boleh diberikan dari mamak ke anaknya. Adanya pantangan adat yang dilanggar kaum jika gelar sako yang telah dilipat tersebut jatuh ke tangan anak dari kaum yang berbeda. Misalnya, seorang mamak tidak 
dibenarkan memberikan gelar sako kaumnya kepada anaknya, walaupun gelar tersebut memiliki harga diri yang tinggi di mata kaum. Begitu juga dengan gelar sako yang diperjualbelikan.

Dalam novel ada kejanggalan-kejanggalan adat yang menuai konflik yang cukup satir. Seorang mamak hendak merebut gelar sako kaumnya untuk diberikannya kepada anaknya. Padahal dalam adat Minangkabau, hal tersebut sangatlah dilarang dan menimbulkan malapetaka bagi kaum. Hal ini terdapat pada kutipan berikut.

Tak usah menemukan Baharudin. Laki-laki itu tinggal di pinggaran kota. Ia membuat rumah dengan pekarangan yang luas. Di pekarangan itu, Baharudin berkebun dan beternak ayam untuk merintangrintang hari. "Aku hendak meminta gelar yang dipinjamnya," ujar Sunur menyampaikan maksud kedatangannya ke ibukota kepada Zakir.

Zakir membalas dengan senyum tertahan. "Ambil saja! Tak perlu Mamak susah-susah memintanya." Kalau bukan karena segan, Zakir ingin melepas tawa atas tabiat mamaknya itu.

Kalau mau, Sunur bisa mengambil begitu saja gelar yang dipinjam Baharudin. Laki-laki itu hanya membutuhkan gelar di ujung masa pensiunan sebagai perwira polisi. Tak beberapa lama menjalani masa pensiunnya, Baharudin tak membutuhkannya lagi. Bahkan, ia tak ingat lagi telah menyandang gelar datuk. Baharudin sudah pikun. Kalau melihat perangainya saat ini yang kembali seperti anakanak, gelar yang disandang tak pantas lagi untuknya. Gugur begitu saja. Sunur bisa mengambil. Tapi, untuk apa gelar itu bagi Sunur? "Untuk anak laki-lakiku." Keinginan Sunur membuat heboh orang-orang di Maransi (Rizal, A. A. 2017: 185-186).

Kutipan di atas menampilkan bahwa Sunur sempat meminjamkan gelar kaum kepada Baharudin. Hal ini diberikannya agar mendapatkan uang dari gelar yang dipinjamkannya tersebut. Setelah menguasai gelar kaum, Sunur pun menginginkannya agar gelar tersebut dapat diberikannya kepada anak laki- lakinya. Kemungkinan diberikannya kepada anak laki-laki supaya mendapatkan harta pusaka kaum yang diinginkannya.

Dalam perebutan gelar tersebut, Sunur harus merebutnya dari Rodiah, saudara perempuannya yang memiliki hak mewariskan gelar kaum untuk anaknya. Sebab dari segi adat, anak Rodiah memiliki hak lebih untuk memperoleh gelar tersebut. Pada novel terdapat dalam kutipan berikut.

Mandeh tak mempermasalahkan Sunur mengambil gelar yang terlipat. Tapi, Rodiah menentang dengan tegas. "Hasratmu itu akan mendatangkan malapetaka!" Seru Rodiah kepada Sunur.

"Halah, kau hanya termakan iri dan dengki. Kau menginginkan gelar itu untuk anak laki-lakimu," balas Sunur.

"Tentu saja Rodiah menginginkan gelar itu untuk anak laki- lakinya. Ia telah bersusah-payah mempersiapkan Farlan. Namun, anak laki-lakinya itu tetap saja disebut belum pantas. Kalau Farlan belumlah pantas, apalagi Sulam. "Kau akan menzalimi anak laki-lakimu itu."

$* * *$

Tanpa persetujuan kaum, Sunur sudah menggembar-gemborkan keinginanya memasang gelar untuk anak laki-lakinya. Ia menyampaikan keinginannya itu kepada Bahrun. "Persiapkan pengkuhan untuk anakku." (Rizal, A. A. 2017: 187).

Dari kutipan di atas terlihat bahwa keinginan Sunur menaruh gelar kaum untuk anak laki-lakinya sudah melewati batas. Padahal, Rodiah telah mengingatkannya jika gelar tersebut akan mendatangkan malapetaka buat Sunur dan anaknya. Nyatanya hal ini malah diindahkannya Sunur dan terus berupaya merebut gelar kaum yang terlipat tersebut.

Dalam menjalankan perannya sebagai mamak, seharusnya Sunur memberikan hak kewajiban saudara perempuannya atas gelar sako yang diturunkan kepada anaknya. Gelar tersebut tidak diperkenankan dalam hukum di 
Minangkabau diambil alih oleh seorang mamak untuk anaknya. Sehingga, mamak kehilangan peran atas tanggung jawabnya mengangkat datuk bagi kaumnya.

Dari pembahasan di atas ditarik kesimpulan bahwa konflk-konflik yang terjadi antara mamak dan kemenakan merupakan kondisi sosial yang mempengauhi adat, tradisi, dan budaya Minangkabau. Konflik sosialnya pun menampilkan peran mamak, kedudukannya, hingga keberadaan harta pusaka kaum yang menjadi objek dari pertikaian. Mamak berkeinginan menguasai harta pusaka berupa rumah gadang, tanah pusaka serta gelar sako yang bukan diperuntukkan bagi anaknya. Sehingga, peran dan kedudukan seorang Mamak mengalami pergeseran dan menyimpang dari yang ada.

\section{PENUTUP}

Novel Maransi karya A.R Rizal merupakan karya sastra yang dikemas dari gejolak, pergeseran, dan konflik sosial masyarakat Minangkabau. Karya ini berlatar tempat Maransi, sebuah daerah dengan perkembangan yang sangat pesat dari segi sosial, ekonomi, adat dan budaya. Persoalan-persoalan yang ditampilkan di dalamnya pun sangat dekat dengan kehidupan masyarakat Minangkabau sendiri.

Di dalam novel ini, tampak beberapa perubahan sosial yang pada akhirnya menimbulkan konflik tokoh. Konflik antartokoh ini kemudian meluas menjadi sebuah konflik sosial oleh karena terjadinya pergeseran peran mamak sebagai orang yang dituakan dalam kaum pada pengambilan keputusan mendirikan rumah gadang, hilangnya citra kepemimpinan mamak dan datuk di masyarakat Minangkabau yang lebih mengedepankan kepentingan pribadinya dan mendahulukan kepentingan keluarga dan anaknya, terjadinya pergeseran peran mamak dalam mengendalikan harta pusaka dan sako sebagai warisan yang harus diturunkan kepada kemenakannya, pewarisan yang terjadi mengalami kejanggalan di mana mamak berusaha merebut gelar sako teruntuk anaknya yang tidak sesuai adat Minangkabau, perilaku mamak yang tidak sesuai dengan hukum adat Minangkabau seperti menjual tanah pusaka, memperebuti gelar sako, dan mempersulit orang lain dalam pengangkatan mamak rumah.

\section{REFERENSI}

Ahmadi, Abu. 1979. Psikologi Sastra. Surabaya: Penerbit PT. Bina Ilmu.

Diradjo, Ibrahim Dt. Sanggoeno. 2009. Tambo Alam Minangkabau: Tatanan Adat Warisan Nenek Moyang Orang Minang. Bukittingi: Kristal Multimedia.

Endraswara, Suwardi. 2003. Metode Penelitian Sastra: Epistemologi, Model, Teori, dan Aplikasi. Yogyakarta: Penerbit Pustaka Widyatama.

Endraswara, Suwardi. 2013. Sosiologi Sastra: Studi, Teori, dan Interpretasi. Yogyakata: Penerbit Ombak.

Escarpit, Robert. 2008. Sosiologi Sastra. Jakarta: Yayasan Obor Indonesia.

Fananie, Zainuddin. 2000. Telaah Sastra. Surakarta: Muhammadiyah University Press.

Fatimah, Siti. 2008. "Mencermati Perubahan Sosial Masyarakat Minangkabau Melalui Novel Tamu karya Wisran Hadi". dalam jurnal Humaniora vol. 20. diakses pada tanggal 24 Januari 2018.

K, Anggi Zoriyati. 2008. "Protes Sosial dalam Novel Sitti Nurbaya karya Marah Rusli: Sebuah Tinjauan Sosiologi Sastra". (Skripsi). Padang. Universitas Andalas.

LKAAM. 2002. Adat Basandi Syarak, Syarak Basandi Kitabullah: Pedoman Hidup Banagari. Padang: Sako Batuah. Marajo, Sjafnir Dt. Kando. 2006. Siriah Pinang Adat Minangkabau: Pengetahuan Adat Minangkabau Tematis. Padang: Sentra Budaya. 
Moleong, Lexy J. 2007. Metode Penelitian Kualitatif. Bandung: PT. Remaja Rosdakarya.

M.S, Amir. 2011. Adat Minangkabau: Pola dan Tujuan Hidup Orang Minang. Jakarta: Penerbit Citra Harta Prima. Navis, A. A. 1984. Alam Takambang Jadi Guru: Adat dan Kebudayaan Minangkabau. Jakarta: Penerbit PT Grafiti Pradopo, Rachmat Djoko. 1994. Prinsip-prinsip Kritik Sastra. Yogyakarta: Gadjah Mada University Press.

Pusat Pengkajian Islam dan Minangkabau (PPIM) Sumbar. 2005. Ensiklopedi Minangkabau: Edisi Awal. Padang: PPIM.

Putri, Fitria. 2014. "Pergeseran Peran Mamak dalam Teks Lagu Minangkabau Analisis Sosiologi Sastra”. (Skripsi). Padang. Universitas Andalas.

Putri, Silvy Riana. 2009. "Kritik Atas Kekuasaan Mamak Terhadap Kemenakan dalam Didjemput Mamaknya oleh Hamka”. (Skripsi). Depok. Universitas Indonesia.

Ratna, Nyoman Kutha. 2003. Paradigma Sosiologi Sastra. Yogyakarta: Pustaka Pelajar.

Ratna, Nyoman Kutha. 2009. Teori, Metode, dan Teknik Penelitian Sastra. Yogyakarta: Pustaka Pelajar.

Rizal, A. A. 2017. Maransi. Bandung: Penerbit Angkasa

Syaputra, Andri. 2012. "Konflik Mamak dan Kemenakan dalam Naskah Randai Kaki Takabek Tangan Baelo karya Irwandi: Tinjauan Sosiologi Sastra”. (Skripsi). Padang. Universitas Andalas.

Taum, Yoseph Yapi. 1997. Pengantar Teori sastra. Flores: Penerbit Nusa Indah.

Zainuddin, H. Musyair. 2010. Implementasi Pemerintah Nagari Berdasarkan Hak Asal-Usul Adat Minangkabau. Yogyakarta: Penerbit Ombak. 